\title{
Savaşın Propaganda Cephesi: İran Sinemasında Suriye İç Savaşı
}

\author{
Nail Elhan*
}

\section{$\ddot{O} z$}

2011 yılında başlayan Suriye'deki iç savaş, devlet ve devlet-dış1 aktörlerin dahli ile birlikte uluslararası bir hal almıştır. Savaşın tarafı olan aktörler, silahlı mücadelelerinin yanı sıra propaganda faaliyetlerinde de bulunmuşlar ve izledikleri politikalara meşruiyet kazandırma çabası içerisinde olmuşlardır. Bu süreçte İran da Suriye İç Savaşı'nda taraf olan ve propaganda faaliyetleri yürüten aktörlerden olmuştur. İran, 1979 yılındaki devrimin ardından değişen dış politika paradigması çerçevesinde Suriye savaşına müdahil olmuş ve savaş sürecinde mezhepçilik yaptığı, iç meselelerini göz ardı ettiği gibi gerekçelerle eleştirilmiştir. Bu eleştirilere karşı yumuşak bir güç olarak sinemayı propaganda aracı olarak kullanan İran, böylelikle hem dış politikada hem de iç politikada meşruiyet zemini aramıştır. Bu aşamada İran yönetimi tarafindan propaganda amaçlı kullanılan "Şam Saatine Göre" filmi, İran'ın bu girişiminin bir ürünü olmakla beraber, devletin Suriye'deki iç savaşı algılayışına ve savaş sürecinde ürettiği söyleme örnek oluşturmaktadır. Çalışma bu bağlamda, 1979'daki İslami devriminden günümüze kadar İran'ın sinemayı bir propaganda aracı olarak kullanışını "Şam Saatine Göre" filminden hareketle, İranSuriye ilişkileri ve Arap Baharı çerçevesinde ele almaktadır. Çalışmada Teun A. Van Dijk'in eleştirel söylem analizi yöntemi kullanılarak "Şam Saatine Göre" filminin analizi yapılmaktadır. İran'ın Suriye'deki savaşı algılayışının görsel ve söylemsel yollar ile yeniden inşa edildiği sonucuna ulaşılmaktadır. Çalışma, Suriye İç Savaşı, Arap Baharı ve İran'ın bu iki meseleye bakış açısı konusunda literatüre katkı sunma amacındadır.

Anahtar Kelimeler: İran, Suriye, Arap Baharı, Suriye İç Savaşı, Direniş Cephesi, Propaganda 


\title{
The Propaganda Front of War: The Syrian Civil War in the Iranian Cinema
}

\author{
Nail Elhan*
}

\begin{abstract}
The civil war in Syria started in 2011, internationalized with the involvement of states and non-state actors into the conflict. The actors in the war involved in propaganda activities as well as armed struggle and were in an effort to legitimize their policies. Iran is one of the actors which intervened in the civil war and carried out propaganda activities. Iran has been involved in the civil war in the framework of the changing foreign policy paradigm after the 1979 revolution. It is criticized because of fueling sectarianism and ignoring internal issues. Iran, which uses cinema and propaganda as a soft force against these criticisms, has thus sought legitimacy in both foreign and domestic politics. The film "Damascus Time," in this respect, is a product of this initiative of Iran. It is an example of Iran's perception of the civil war, its rhetoric and discourse during the civil war. In this regard, the study deals with Iran's use of cinema as a propaganda tool since the Islamic Revolution of 1979 within the context of Iran-Syria relations and the Arab Spring. In this study, Teun A. Van Dijk's critical discourse analysis method is used in order to analyze the film, "Damascus Time." It is concluded that Iran's perception of war in Syria is reconstructed through visual and discursive ways. The study aims to contribute to the literature on the Syrian civil war, the Arab Spring and Iran's perception of these two events.
\end{abstract}

Keywords: Iran, Syria, Arab Spring, Syrian Civil War, Resistance Front, Propaganda

Res. Asst., Hitit University, TR, department of International Relations, orcid.org/00000002-5058-0280, nail.elhan@gmail.com 


\section{Giriş}

Orta Doğu'nun geneline etki eden Arap Baharı'nın bir parçası olarak Suriye'de başlayan iç savaş, Başar Esad'ın liderliğini yaptı̆̆ 1 Baas Partisi rejimi, onun destekçileri ve ona karşı çıkan muhalif güçler arasında 2011 yılında başlamıştır. İnsan hakları, demokrasi ve ekonomik şartların iyileştirilmesi gibi istekler ile ortaya çıkan muhalefet, Suriye'deki mevcut rejimin değişmesi talebinde bulunmuştur. Söz konusu talepler ile ortaya çıkan ve Tunus, Mısır gibi ülkelerde diktatörlüklerin yıkılması ile başarıya ulaşan bu söylem, Suriye muhalefetine de ilham vermiştir. Ancak, Suriye ordusunun göstericilere karşı sert tutumu ve ülke çapında muhalefeti silahla bastırma politikası karşılıklı silahlı çatışmalara yol açmış; ülke, barışsız bir geleceğe ilk adımını atmıştır. Yaşanan gelişmeler, zaman içerisinde meseleye bölgeden ve bölge dışından çok sayıda aktörün dâhil olmasına kap1 aralamıştır. IŞiD $^{1}$ ve El Nusra gibi radikal örgütlerin Suriye muhalefeti arasında güç kazanması ve dişarıdan Suriye'ye gelen çok sayıda cihatçının iç savaşa dâhil olması ile birlikte, Suriye İç Savaşı uluslararası bir mesele haline bürünmüştür. Olası bir rejim değişikliği ve bunun ortaya çıkaracağ sonuçlar, ideolojik ve politik motivasyonlarla hareket eden devletlerin ve devlet dışı aktörlerin harekete geçmesine neden olmuştur. Sonuç olarak, 2011 yılında başlayan Suriye İç Savaşı, günümüze gelindiğinde çok sayıda devletin ve devlet dışı aktörün birbirlerinden çok farklı siyasal amaçlarla dâhil olduğu, bunlar arasında barışı öteleyip savaşı kısa bir süreliğine erteleyen çoğu ateşkesin yapıld $1 \breve{g}^{2}$ ve bu süre zarfında çok sayıda sivilin hayatını kaybettiği ve bir o kadarının da ülkelerini terk etmek zorunda kaldığ uluslararası bir mesele haline gelmiştir.

Uluslararasılaşan iç savaş, sadece karşıt grupların birbirleri ile silahlı mücadelesine tanık olmamış, kullanılan sert gücün yanı sıra, aktörlerin çoğu, savaşta bulunmalarına ve silahlı faaliyetlerine meşruiyet kazandıracak,

Irak Şam İslam Devleti'ni ifade etmek amacıyla çeşitli dillerde farklı kısaltmalar kullanılmaktadır. Örneğin Türkçe kısaltması olarak IŞīD, Arapça ve İngilizce kısaltmalar olarak da DAEŞ (ad-Dawlah al-Islamiyah fil-'Iraq wa ash-Sham) ve ISIS (Islamic State in Iraq and Syria) ifadeleri kullanılmaktadır. Bu çalışmanın konusu olan filmde de IŞiD, DAEŞ olarak anılmaktadır. Karışıklığa yol açmaması açısından, bu çalışmada Irak Şam İslam Devleti'nin Türkçe kısaltması olan IŞṠiD ifadesi kullanılmaktadir.

2 Bu ifade, David Fromkin'in A Peace Ending the All Peace kitabının başlığından esinlenilerek kullanılmıştır. 
kendilerine yeni militanlar ve destekçiler katacak, aynı zamanda hem rakiplerine, hem de dünya kamuoyuna olumlu ya da olumsuz mesaj verecek propaganda politikaları da izlemişlerdir. Video savaşları olarak anılan ve Esad yanlıları ile muhaliflerin birbirlerini sivillere karşı kimyasal saldırılarda bulunmakla itham etmelerine ilişkin görüntü ve açıklamalar, ${ }^{3}$ silahlı örgütlerin propaganda malzemesi olarak müzik ve marş kullanımları, ${ }^{4}$ sosyal medyanın bir propaganda aracı haline getirilmesi ve özellikle IŞì'in katliam görüntülerini profesyonel yöntemler ile videolaştırması ve yayma$\mathrm{S1}^{5}$ bu kapsamda değerlendirilebilecek örneklerdendir. Özellikle IŞİD’in faaliyetlerine bakıldığında, propagandanın örgütün stratejisinde ne denli merkezi bir role sahip olduğu ortaya çıkmaktadır. Örgüt, neredeyse gerçekleştirdiği her faaliyeti birer medya çıktısına dönüştürmektedir. ${ }^{6}$

Devletlere bakıldığında ise propaganda faaliyetlerinin örgütlere kıyasla daha geniş kaynaklar kullanılarak, daha geniş kitleler için tasarlandığ söylenebilir. Savaş dönemlerinde daha da yoğunlaşan bu durum, Suriye İç Savaşı'nda da dikkat çekmektedir. Suriye İç Savaşı'nın tarafı olan devletler, savaştaki rollerini hem iç kamuoylarına hem de uluslararası topluma açıklama gereği içerisindedirler. İran da hem Suriye'deki savaşın önemli taraflarından, hem de propaganda savaşlarının önemli aktörlerinden biridir. İran, Arap Baharı olarak tanımlanan ayaklanmaların başlaması ve zamanla bölgeye yayılması ile birlikte yaşananları 'İslami Uyanış’ olarak nitelendirmiş ve söz konusu hareketlerin 1979 yılındaki İran Devrimi’nden esinlenerek ortaya çıktığını iddia etmiştir. Ayaklanmaların Suriye'de de başlaması ile birlikte bu iddiasını terk etmiş ve Suriye'deki muhalefetin Batı ve İsrail yanlısı olduğunu vurgulamaya başlamıştır. Suriye'deki iç savaşın önemli

Robert Bunker, "The Assad Regime and Chemical Weapons," Strategic Insights, 18 May1s 2018, https://ssi.armywarcollege.edu/index.cfm/articles/Assad-RegimeChemical-Weapons/2018/05/18

4 Agâh Hazır, "Suriye İç Savaşı'nda Müzik Cephesi: Örgütler ve Şarkılar Üzerine Bazı Gözlemler," Orta Doğu Analiz 7, no. 71 (2015): 80-82. Agâh Hazır, "Reflections on Musical Propaganda in the Syrian Civil War: A Comparison of the PKK/PYD, Daesh and Hezbollah," Current Debates in International Relations \& Law içinde, Editörler: Övgü Kalkan Küçüksolak \& Abdullah Muhsin Yıldız, (Londra: IJOPEC Publication, 2018), 169-177.

5 “IŞiD’in Yeni Propaganda Arac1: İnstagram,” BBC, 22 Eylül 2017, https://www.bbc. com/turkce/haberler-dunya-41360381

6 Bünyamin Ayhan \& Muhammet Emin Çifçi, "IŞiD, Propaganda ve İslamofobi," Medya ve Din Araştırmaları Dergisi 1, no. 1 (2018): 17-32. 
aktörlerinden olan ve rejimin yanında yer alan İran, Suriye'nin bölgedeki en önemli müttefiklerinden biridir. ${ }^{7}$ Suriye'deki iç savaşa dâhil olan ülke, bölge stratejileri ve öngörüleri kapsamında, politikalarında propagandaya da sıkça yer vermektedir. Bu çalışma, İran'ın Suriye İç Savaşı'na dâhil olmasını, savaştaki rolünü ve savaşa bakışını 2018 yılında sinemalarda gösterime giren ve İran'ın IŞiD karşıtı mücadelesini ele alan "Şam Saatine Göre" adlı propaganda filmi üzerinden değerlendirecektir. ${ }^{8}$ Bu bağlamda, İran'ın Suriye'deki iç savaşa bakışı, IŞiD algısı, dini mesajları, İsrail politikası ve iç politikasındaki gelişmelere yaklaşımı ele alınacaktır. Çalışma bu kapsamda beş ana bölümden oluşmaktadır. İlk bölümde, çalışmanın amacı ve çalışmada kullanılan metot açıklanacaktır. İkinci bölümde, propagandanın önemi, sinemanın bir propaganda aracı olarak ortaya çıkışı ve İran'ın sinemayı bir propaganda aracı olarak kullanımı üzerinde kısaca durulacaktır. Üçüncü bölümde, İran-Suriye ilişkilerinin ve İran'ın Suriye'ye verdiği desteğin arkasındaki zihniyet ele alınacaktır. İran'ın Suriye'deki iç savaşta izlediği politikalar ve geliştirdiği argümanlar tartış1lacaktır. Dördüncü bölümde, "Şam Saatine Göre" filminin künyesine ve konusuna ilişkin bilgiler verilecek ve filmin İran'da aldığı tepkiler üzerinde durulacaktır. Son bölümde ise söz konusu film üzerinden İran'ın Suriye İç Savaşı'nı algılayışı, savaştaki söylemleri ve bunların iç politika ile bağlantıları çalışmada kullanılan eleştirel söylem analizi yöntemi bağlamında ele alınacak ve elde edilen bulgular açıklanacaktır.

Rafke Risseeuw, “The Syrian-Iranian Nexus: A Historical Overview of Strategic Cooperation," Research, (Brussels: Brussels International Center for Research and Human Rights, 2018): 3.

8 Son dönemde Suriye'deki savaşı konu eden ve çoğu belgesel türünde birçok film çekilmiştir. Halep'in kuşatılmasını ve Beyaz Kasklılar adlı sivil savunma örgütünün sivillere yaptıkları yardımı belgesel şeklinde aktaran Last Men in Aleppo (2017), iç savaşı eski bir radyo DJ'inin gözünden aktaran The War Show (2016), Suriye ordusu tarafından bombalanan Humus şehrinde iki genç erkeğin gündelik yaşamlarının ve savaşın yaşamları üzerindeki etkilerinin anlatıldığı The Return to Homs (2013), Suriyeli mültecileri konu eden Salan Neighbor (2015), Suriyeli siviller, savaşçılar, aktivistler ve gazeteciler ile yapılan mülakatlardan oluşan belgesel film Cries from Syria (2017), Suriye'de muhalefetin isteklerini ve taleplerini ele alan Red Lines (2014), sivil savaşın yol açtığı insani yıkıma odaklanan 7 Days in Syria (2015) ve Türkiye-Suriye sınırına mültecilere yardım etmek amacı ile giden bir doktorun serüvenini anlatan 50 Feet from Syria (2015) bu filmlerden bazılarıdır. 


\section{Amaç ve Yöntem}

Bu çalışmanın amacı, İran'ın sinemayı kullanarak Suriye İç Savaşı'na dahlinin meşruluğunu hem iç, hem de dış kamuoyuna ideolojik söylemler üzerinden sağlama gayretinin açıklanması ve ortaya çıkarılmasıdır. Çalışma, İran'ın dış politikasını ve güncel bir konu olan Suriye İç Savaşı'nı ele alan literatür tarafindan yeterince çalışılmamış bir mesele üzerinde durmakta olup İran'ın iç savaşa dahil olduktan sonra politikalarına meşruiyet kazandırma çabasının sinemada nasıl inşa edildiğini açıklamayı amaçlamaktadır. 2018 yılında gösterimi yapılan "Şam Saatine Göre" filmi, hem İran'ın dış politika öncelikleri, hem de Suriye meselesine yaklaşımını göstermesi bakımından örneklem olarak seçilmiş ve değerlendirilmiştir. Çalışmada Teun A. Van Dijk'in eleştirel söylem analizi (ESA) yönteminden faydalanılmıştır. Dijk'in analizi; metnin ideolojik sunumunu açıklaması, ideoloji, söylem ve dil gibi kavramlara odaklanması, ideoloji ve söylem arasındaki ilişkiyi detaylandırması ve sosyal koşullar ile süreçleri dikkate alması bakımından önem taşımaktadır. ${ }^{9}$ ESA, paradigma odaklı olmaktan çok konu ve sorun odaklıdır. Söylemin üstü örtülü olarak amaçladığını ortaya çıkarmayı amaçlamaktadır.

İdeolojinin, fikirlerin ve anlamların ortaya çıkarılabilmesi için söylem analizi gerekmektedir. Dijk'in bu bağlamda kullandığı yöntem metnin retoriğini ve anlatısını kapsamakta olup iki başlık altında ele alınmaktadır. Bunlardan ilki, sesleri, sözcük seçimlerini ve cümle yapılarını ele alan mikro çözümleme yöntemidir. İkincisi ise tematik ve şematik anlatı üzerine odaklanan makro çözümleme yöntemidir. Ekinci'ye göre dil, söylem analizinin en önemli veri kaynağıdır ve kendine has metinleri ve söylemi ile sinema da bir dil yapısına sahiptir. ${ }^{10}$ Sinemada diyaloglar, oyuncular ve kullanılan mekân ile bir araya gelerek anlamlı bir bütün oluşturmakta, görsel bir söylemde bulunmaktadır. ${ }^{11}$ Bu bağlamda, Dijk'in analizinin sinema filmlerine uygulanması mümkündür. Bu çerçevede, Dijk'in önerdiği makro ve mikro

Teun A. Van Dijk, "Principles of Critical Discourse Analysis," Discourse \& Society 4, no. 2 (1993): 249-283.

10 Barış Tolga Ekinci, “Argo Filmi Bağlamında Hollywood Sinemasında Söylem ve Yeni Oryantalizm,” Atatürk İletişim Dergisi, no. 6 (2014): 56-57.

11 Lokman Zor, "Van Dijk'in Eleştirel Söylem Analizinin Sinema Filmlerine Uygulanması ve Kazakistan Sineması'ndan Örnek Bir Film Çözümlemesi: Stalin'e Hediye," Akademik Bakış Dergisi, no. 61 (2007): 881. 
yapılar, sinema filmlerinin söylemsel özellikleri dikkate alınarak bu çalışmada kullanılacaktır. Çalışmada filme ait görsel özellikler ve giriş/sonuç sekansı gibi ögeler mikro yapı içerisinde değerlendirilecektir. Filmin öyküsü, olay örgüsü, filmdeki karakterler ve yerler ise makro yapı çözümlemesi kapsamında analiz edilecektir. Filmin söylem çözümlemesi bu modele göre yapılacak olup bulgu ve analizler "Şam Saatine Göre" İran'ın Suriye Politikası başlıklı bölüm altında incelenecektir.

\section{Propaganda, Sinema ve İran}

Propaganda, düşüncelerin denetimi, kontrol edilmesi ve yönlendirilmesi anlamlarına gelmektedir. ${ }^{12}$ Kitlelerin davranışlarını ve düşüncelerini etkilemek amacı için kullanılan propaganda ve metotlar, tarihi süreç içerisinde gelişmiştir. Medyanın bir propaganda unsuru olarak kullanılmaya başlanması, kaçınılmaz olarak sinemadan da bir araç olarak yararlanılmasının önünü açmıştır. Sinema, yaygın ve popüler bir araç olması hasebiyle sosyal, siyasal ve kültürel alanda önemli bir role sahiptir. Bu nedenle, düşüncelerin ifade ve empoze edilmesinde etkisi oldukça fazladır. Sinemanın propaganda faaliyeti olarak kullanılması, onun bu özelliğinden kaynaklanmaktadır. Sinema, orduların ve silahların yapabileceğinden daha fazlasını, daha etkili olarak ve daha az maliyetle kitlelere ulaştırabilmesi nedeniyle sıkça başvurulan bir araç haline gelmiştir. Özdemir'in de ifade ettiği üzere, ateşli silahların kitlelere yönelik en önemli kabiliyeti "imha" iken, propagandanın "ikna" etkisi yadsınamayacak bir güçtür. ${ }^{13}$ Bu bağlamda, sinemanın bir propaganda aracı olarak kullanılması, 'insan zihinlerinin zapt edilmesi' sürecinde etkili ve önemli bir araç olarak görülmelidir. ${ }^{14}$

Savaş, sinema ve propaganda arasındaki ilişki Birinci Dünya Savaşı dönemine kadar götürülebilir. Modern tarihe büyük bir yıkım olarak geçen bu savaş, aynı zamanda filme kaydedilen insan yapımı ilk felakettir. ${ }^{15}$ Günü-

12 Rejandra Kumar Sharma, Social Change and Social Control (Yeni Delhi: Atlantic Publishers, 1997), 285.

13 Seçil Özdemir, “İran'ın Bir Dış Politika Enstrümanı olarak Propaganda” IRAM Analiz. Ankara: İran Araştırmaları Merkezi (İRAM), (2017): 5.

14 Garth Jowett \& Victoria O'Donnell, Propaganda and Persuasion, (Londra: SAGE Publications, 2006), 50.

15 Christina Stojanova, "The Great War: Cinema, Propaganda, and The Emancipation of Film Language," Acta Universitatis Sapientiae, Film and Media Studies, no.14 (2017): 132. 
müze gelindikçe, ülkeler sinemanın kitleleri mobilize etme potansiyelini kavramaya ve onu bir propaganda aracı olarak kullanmaya başlamışlardır. Hollywood'un bir dış politika enstrümanı olarak ABD tarafından kullanım $1^{16}$ ve Sovyetler Birliği'nin sinemayı hem iç, hem de diş politikada bir propaganda unsuru olarak kullanması bunun en önemli örneklerindendir. ${ }^{17}$ Uzun vadede düşünüldügünde, kitlelerin algılarını ve eylemlerini yönlendirmede etkili bir güç olan propaganda, İran tarafından da sıklıkla başvurulan bir yöntem olmuştur. Özellikle 1979 yılındaki devrimin ardından resimler, posterler ve tarihten beslenen dini görüntüler ile İran'da etkili bir propaganda kültürü oluşmuştur. Popüler inanışlar ve ritüeller pullara, banknotlara ve sakız ambalajlarına dönüştürülmüştür ve devrim ve savaş için toplu bir seferberliğe yönlendirilmiştir. ${ }^{18}$ Sinema ise bir propaganda aracı olarak devrimin henüz ilk yıllarında keşfedilen bir alan olmuştur.

1979 yılındaki devrimden sonra kurulan yeni rejim, mevcut anlayışı değiştirerek Batı'dan bağımsız ve ahlaka uygun bir yeni sinema kurma gayreti içerisinde olmuştur. Devrimin ilk yıllarında çok sayıda sinema, ahlaksızlık ve Batı yanlısı olma gibi gerekçelerle kapatılırken, devrimin lideri Ayetullah Humeyni sinemaya karşı olmadıklarını, ama ahlakın da önemli bir unsur olduğunu vurgulamıştır. ${ }^{19}$ Humeyni’ye göre, bir film yüz cilt kitap ve dergiden daha fazla etki gücüne sahiptir ve İslami rejimin halka anla-

16 David Robb, Operation Hollywood: How the Pentagon Shapes and Censors the Movies. (New York: Prometheus Books, 2004); Tony Shaw, Hollywood's Cold War, (Edinburgh: Edinburgh University Press, 2007); Tony Shaw, Cinematic Cold War: The American and Soviet Struggle for Hearts and Minds, (Kansas: University Press of Kansas, 2010); Usama Shafique \& T. A. Khan, "Hollywood Propaganda Movies and Muslims," Journal of Mass Communication, no.8 (2013): 65-77.

17 Çağrı İnceoğlu, "Sovyet Propaganda Animasyonlarında Batı ve Batılı İmgesi," Galatasaray Üniversitesi İletişim Dergisi, no.19 (2013): 23-40.

18 Peter Chelkowski, \& Hamid Dabashi, Bir Devrimi Sahnelemek: Iran İslam Cumhuriyeti'nde Propaganda Sanatı, (İstanbul: Kitap Yayınları, 2018), 6. Ayrıca Bu konuda yapılmış örnek çalışmalar için bkz. Nail Elhan, "Banal Nationalism in Iran: Daily Re-Production of National and Religious Identity," Insan ve Toplum 6, no.1 (2016): 119-136 ve Nail Elhan, “İran'ın Uluslaşma Sürecinde Süreklilik ve Değişim: Banknotlar ve Posta Pulları Üzerine Bir İnceleme," Akademik Orta Doğu 11, no.2 (2017): 85-97.

19 Agnes Devictor, "Classic Tools, Original Tools: Cinema and the Public Policy in the Islamic Republic of Iran (1979-1997)," The New Iranian Cinema: Politics, Representation and Identities içinde, Editör: Richard Tapper, (Londra: I.B. Tauris, 2002). 66-76. 
tımı sinema vasıtası ile daha kolay olacaktır. ${ }^{20} \mathrm{Bu}$ bağlamda, sinemanın dini açıdan günah olmadığı açıklaması ile işe başlanmıştır ve devlet, milli bir sinema oluşturmak amacı ile sektöre girmiştir. Hem sağlayıcı (promoting), hem de kontrol edici (monitoring) olarak sektörde yer edinen devlet, bir yandan ahlaki ve dini kontrol yaparken, diğer taraftan da sinemacılara ekonomik destek vermiştir. Rejimin ön plana çıkarma gayretinde olduğu temaları işleyen filmler özellikle teşvik edilmiştir. Örneğin, İslami değerleri konu eden, Şah dönemlerini eleştiren ve Irak ile yapılan savaşı anlatan filmler desteklenmiştir. ${ }^{21} \mathrm{Bu}$ çerçevede devlet, 1984 yılından itibaren savaş filmi yapımına öncelik vermiş ve kahramanlarını genellikle Devrim Muhafızları Ordusu (DMO)'dan ve Irak ile devam etmekte olan savaşta 'şehit' olanlardan ve dini liderlerden seçmiştir. Kahramanlar, az konuşan ve çok iş yapan suradan insanlar olarak resmedilmişlerdir. Filmlerde, şehadet kavramı ve şehitler önemli unsurlar olarak yer almıştır ve savaş, vatan müdafaası olduğu kadar dini bir vazife olarak da ele alınmıştır. ${ }^{22}$ Rejimin hem ülkedeki nüfuzunu arttırabilmesi, hem de yeni kanunların halk tarafindan benimsenmesi amacıyla propaganda amaçlı yararlanılan sinema, İran-Irak Savaşı'nda cepheye taşınmıştır. ${ }^{23}$ Irak'ın 1980 yılında İran'a saldırması ile başlayan ve sekiz yıl süren savaş, bu tür filmlerin yapılmasında ve yönetmenlerin yetişmesinde önemli bir tetikleyici unsur olmuştur. "Şam Saatine Göre" filminin yönetmeni olan İbrahim Hatemikiya da film çalışmalarına bu süreç içerisinde başlamıştır. ${ }^{24}$

İran'ın sinemayı bir propaganda aracı olarak kullanımının, Suriye'de 2011 yılında başlayan iç savaş sürecinde de devam ettiği gözlemlenmektedir. İç savaşı birinci dereceden bir güvenlik meselesi olarak gören İran, savaştaki rolünü ve önceliklerini sinema vasıtası ile propagandalaştırma gayreti içerisinde olmuştur. Sinemanın Suriye'deki iç savaş sürecinde İran tarafindan bir propaganda aracı olarak kullanımına geçmeden önce, İran'ın Suriye ile ilişkilerinin ve Suriye İç Savaşı algısının açıklanması önemlidir.

20 Sabire Batur, Siyasal İslam Sineması Örneğinde Iran Sineması. (Doktora Tezi, Dokuz Eylül Üniversitesi, 2007): 92.

21 Batur, Siyasal İslam Sineması Örneğinde İran Sinemast, 110-111.

22 Mahrokh Shirinpour, Iran Sineması, (İstanbul: Es Yayınları, 2007), 125.

23 Caner Çak1, "İran-Irak Savaşında Kullanılan İran Propaganda Posterlerinin Gösterge Bilimsel Analizi," İran Çalışmaları Dergisi 2, no.1 (2018): 20.

24 Mahrokh Shirinpour, Iran Sineması, 120. 


\section{4. İran-Suriye İlişkileri ve Suriye İç Savaşı}

İran ve Suriye arasındaki yakın ilişkiyi, 1979 yılında gerçekleşen İran Devrimi'ne kadar götürmek mümkündür. 1979 yılındaki İslami devrim ile birlikte İran'da ABD ve İsrail ile yakın ilişkileri olan Şahlık rejimi y1kılarak, yerine önceki dönemin neredeyse tam tersi bir yönde $A B D$ ve İsrail karşıtı bir rejim kurulmuştur. İran'ın devrim sonrası değişen tavrı onu, o yıllarda İsrail ile barış görüşmeleri yürüttüğü gerekçesi ile Mısır ile ve sınır anlaşmazlıkları neticesinde ise Irak ile gergin ilişkilere sahip olan Suriye'ye yakınlaşmaya sevk etmiştir. Filistin meselesinde benzer politikalar benimseyen ve Irak ile gergin ilişkilere sahip iki ülke, belirli ortak politikalar etrafında birleşmişlerdir. Nitekim Suriye, İran'da kurulan İslami rejimi Arap dünyasında tanıyan ve desteklediğini belirten ilk ülke olmuştur. O dönemde Suriye Dışişleri Bakanı olan Abdulhalim Haddam, Ağustos 1979'da Tahran'a yaptığı ziyarette İran Devrimi'ni “çağdaş tarih içerisindeki en önemli olay” olarak nitelendirip, Suriye'nin İran Devrimi’ni "daha ortaya çıkmadan önce, devrim sırasında ve sonrasında" desteklediğini ifade etmiştir. ${ }^{25}$ İki ülke ilişkileri, 1980 yılında Irak'ın İran'a saldırmas1 ile başlayan ve sekiz yıl süren savaştan sonra ve 1982 y1lında İsrail'in Lübnan'1 işgal etmesinin arkasından gelen süreç içerisinde daha da yakınlaşmıştır. Suriye, 1980 ve 1988 yılları arasındaki savaşta Irak'a karşı İran'1 destekleyen az sayıda ülkeden biridir. Suriye'nin amacı, Arap dünyasında kendisine rakip bir ülke olan ve İran'a karşı olası bir zaferde kendisine tehdit oluşturacak olan Irak'1 dengelemektir. Diğer taraftan, 1982 y1lında Lübnan'ın İsrail tarafından işgal edilmesi, Suriye'yi de İsrail tehdidi altına sokmuştur. Çıkar birlikteliği olan Suriye ve İran, bu süreç içerisinde Lübnan'da Hizbullah'ın kurulmasına destek olmuşlardır. Hizbullah'ın kurulması ile birlikte, ileride bölgede İsrail ve ABD'nin çıkarlarını tehdit edecek olan 'Direniş Cephesi' de tamamlanmıştır.

2011 yılında Arap Baharı'nın bir parçası olarak Suriye'de başlayan iç savaş ile birlikte İran-Suriye ilişkileri farklı bir boyuta taşınmıştır. İran, Arap Baharı'nın başında Tunus ve Mısır gibi ülkelerde başlayan halk hareketlerini 1979 yılındaki İran Devrimi'nden ilham alan ve Batı yanlısı yönetim-

25 Bayram Sinkaya, “İran-Suriye İlişsileri ve Suriye'de Halk İsyanı,” Orta Doğu Analiz 3, no. 33 (2011): 39 . 
lerini düşürmeyi amaçlayan bir İslami Uyanış olarak değerlendirmiştir. ${ }^{26}$ Buna göre, İran Devrimi'nin başarılarının bölge halklarına örnek olmaya devam ettiği iddia edilmiştir. İran'ın bu süreçteki temel hedefi bölgedeki Batı yanlısı yönetimlerin halk hareketleri aracılığıyla ortadan kalkması ve onların yerine İran'ın yakın ilişkide bulunabileceği rejimlerin kurulması ve bu süreç içerisinde İran'ın yükselişine zemin hazırlayan dinamiklere zarar verilmesini engellemek olmuştur. ${ }^{27}$ Ancak, halk hareketlerinin 2011 yılında Suriye'de de ortaya çıkması ile İran'ın Arap Baharı söyleminde değişiklikler ortaya çıkmıştır. Suriye'de başlayana kadar İran Devrimi'nden ilham alan ve İslami Uyanış olarak adlandırılan halk hareketleri, Suriye'de gösterilerin artması ile birlikte ABD ve İsrail'in komplosuna evrilmiştir. ${ }^{28}$

İran'ın Suriye'de iç savaşın başlamasından itibaren üç aşamalı bir tutum içerisinde bulunduğu iddia edilebilir. Ayaklanmaların henüz ilk safhasında, Suriye'nin muhaliflere karşı aşırı güç kullanımını eleştiren İran, Suriye'ye sorunun siyaset kullanılarak ve silahsız çözülmesi gerektiği çağrısında bulunmuştur. Bu kapsamda, Esad reform yapmaya ve sorunları diyalog ile çözmeye davet edilmiştir. Bu aşamada İran'ın desteği gösterilerin bastırılması için danışmanlık yapmak ve muhalefetin takibi için teknik cihazlar temin etmekten ibarettir. 2012 yılında çatışmaların şiddetlenmesi ve silahlı radikal örgütler ile muhalefetin rejim karşısında güçlenmesi, İran'ı ikinci aşamaya getirmiştir. Süreç içerisinde küresel güçlerin pozisyonlarının netleşmesi ile İran'ın da rejime olan askeri ve ekonomik desteği artmıştır. Arap Baharı'nın yaşandığı diğer ülkelerden farklı olarak, Suriye'deki olaylar demokratikleşme talep eden hareketler olarak değerlendirilmemiş ve halkın özgürleşmesi olarak görülmemiştir. Tam aksine, muhalefetin faaliyetleri İsrail'in ve ABD'nin desteğini alan ve Direniş Cephesi'nin bölgedeki gücünü zayıflatmayı amaçlayan bir girişim olarak görülmüştür. Zira Direniş Cephesi'nin faaliyet ve etki alanı Suriye'de iç savaşın başlaması

26 Hakk1 Uygur, "İran ve Arap Baharı," SETA Analiz 52, (Ankara: SETA, 2012): 11-12; Narges Bajoghli \& Arang Keshavarzian, "Iran and the Arab Spring," The Arab Spring: The Hope and Reality of the Uprisings içinde, Editörler: Haas, Mark \& Lesch, David. (Boulder: Westview Press, 2017), 174-193.

27 Gülriz Şen, "İran ve Arap Baharı: Bağlam, Söylem ve Siyaset," Orta Doğu Etütleri 3, no. 2 (2012): 100.

28 Ali Ansari, “İran Yazı, Arap Baharı'na Karşı,” Aljazeera, Aralık 25, 2013, http://www. aljazeera.com.tr/gorus/iran-yazi-arap-baharina-karsi 
ile tehdit altına girmiştir. ${ }^{29}$ Suriye' de mevcut rejimin yıkılması ve yerine Batı yanlısı bir rejimin kurulması ihtimali, İran'ın Hizbullah ile bağlantıs1nın kopmasına ve Direniş Cephesi'nin etki gücünü kaybetmesine yol açabilecektir. Son aşamada ise İran, DMO'dan askerleri Suriye'ye göndererek savaşın doğrudan bir parçası olmuştur. DMO bünyesindeki Kudüs Gücü, Suriye'de doğrudan çatışmalar içerisinde bulunmuştur. ${ }^{30}$

İran, Suriye'deki iç savaşa dahlini iki retorik üzerine kurmuştur. Bunlardan birincisi, terörizme karş1 savaştır. Buna göre, Suriye'deki güç boşluğundan faydalanarak güçlenen IŞİD ve El Nusra gibi aktörlerin uygulamaları terör faaliyetleri olarak görülmüştür. Bu örgütlerin Suriye'de yaşayan Şii nüfusa ve Şiilerin kutsal saydıkları mekânlara yönelik saldırıları birer terör eylemi olarak görülmüştür ve bu saldırılara karşı 'engelleyici' saldırıların yapıldığ iddia edilmiştir. İran'ın savaşa dahlini temellendirdiği ikinci retorik ise direniş cephesinin korunmasıdır. Böylelikle, İran'ın bölgedeki en önemli müttefiklerinden Suriye'nin korunması amaçlanmıştır. Zira Suriye, İran'ın dışişleri eski bakanı Ali Ekber Velayeti tarafından direniş cephesinin altın halkası olarak tanımlanmıştır. ${ }^{31}$

Devrim sonrasında İran'ın bölgedeki en önemli kazanımı, İsrail karşısında Filistin direnişine verdiği desteğin, Lübnan'da Hizbullah'ın güçlenmesinin ve Suriye ile kurulan yakın ilişkinin bir sonucu olarak güçlü bir eksen kurmuş olmasıdır. İran bu ekseni siyasi, finansal ve lojistik vasıtalarla desteklemektedir. Örneğin Hizbullah'ın Lübnan'da siyasi varlı̆̆ını ve İsrail'e karş1 gücünü koruması, İran'ın Suriye üzerinden göndereceği yardımlara bağlıdır. Dara Conduit bu bağlamda, İran'1 Hizbullah'ın oksijen deposu olarak nitelendirirken, Suriye'yi de bu oksijeni taşıyan hava borusu olarak tanımlamaktadır. ${ }^{32}$ Suriye, yalnızca bir müttefik değildir. Aynı zamanda, İran'ın savunma stratejisine stratejik derinlik kazandırması açısından son derece değerlidir. ${ }^{33} \mathrm{Bu}$ bağlamda, devrim veya isyan yoluyla Suriye'de

29 Anoushirvan Ehteshami, Iran: Stuck in Transition. (Routledge: Londra, 2017), 234.

30 Nader Uskowi, Temperature Rising: Iran's Revolutionary Guards and Wars in the Middle East, (Londra: Rowman \& Littlefield, 2019), 64.

31 Bayram Sinkaya, "Suriye Krizi Karşısında İran'ın Tutumu ve Şam-Tahran İttifakının Temelleri," Akademik Orta Doğu 10, no. 1, (2015): 135.

32 Dara Conduit, "Hizballah in Syria: The Limits of the Democracy/Moderation Paradigm.” Orta Doğu Etütleri 5, no. 2, (2014): 102.

33 Bayram Sinkaya, “İran'ın Suriye Stratejisi,” Akademik Orta Doğu 11, no. 2, (2017): 50 . 
Esad yönetiminin yıkılması, 'direniş ekseninin altın halkasının' kopması anlamına gelecektir ve İran bölgedeki en önemli güç unsurlarından birisini kaybedecektir. ${ }^{34}$ Bundan İran'ın, Hizbullah da dâhil, bölgedeki diğer müttefikleri de olumsuz etkilenecektir ve bölgesel güçleri zayıflayacak, etkileri azalacaktır. Bu nedenlerle İran, Suriye'deki iç savaşa dâhil olmuştur ve bölgede kendisi ile ilişkili olan tüm aktörlerle Suriye muhalefetine karşı rejimin yanında savaşmıştır. ${ }^{35}$ Her ne kadar rejimi ayakta tutmayı başarmış olsa da, Suriye konusunda İran'ın dış politikasına yön veren iki ilkenin çatıştığı gözlemlenmektedir. Bu ilkeler, otoriter rejimlere karşı mazlum halkların savunulması ve İsrail'e karşı mücadeledir. 1979 yılındaki devrimden bu yana, Humeyni'nin mustazafin olarak adlandırdığı baskı altındaki halkların savunulması, İran'ın öncelikli politikalarından olmuştur. Bu bağlamda İran Anayasası'nın 154. Maddesi, "İran; toplumların tümünde insan saadetini kendi gayesi bilir ve bağımsızlık, hürriyet, hak ve adalet yönetimini dünya insanlarının tümünün hakkı olarak tanır. Diğer milletlerin iç işlerine her tür müdahaleden tam olarak kaçınmakla beraber mazlumların zalimlere karşı haklı mücadelelerini dünyanın neresinde olursa olsun himaye eder" demektedir. İsrail karşıtlığı ise devrimden günümüze kadar İran'ın en önemli dış politika ilkelerinden olmuştur. İran, Suriye'de Esad'1 savunarak İsrail'e karşı mücadelede müttefikinin yanında yer almıştır. ${ }^{36}$ Suriye'de rejimi desteklemek, İran'in resmi ve anayasal söylemi olan mazlum halkların yanında durma ilkesine ters düşse ve diktatörü desteklemek anlamına gelse de, İran için İsrail'e karşı mücadele bir varlık sebebi, raison d'être, olarak daha ağır basmıştır. Suriye'de rejimin tehdit edilmesi, İran'ın da güvenlik meselesi olarak görülmüsşür. ${ }^{37}$ İran, sinemanın sağladığ 1 propaganda gücünü öncelikle devrimi ayakta tutabilmek ve bölgede etkin bir devlet olabilmek için kullanmaktadır. ${ }^{38}$ Bu kapsamda, Suriye'deki savaşa dahli mezhepçilik kapsamında değerlendirilen İran, kendisini bu ithamlar-

34 Bayram Sinkaya, “Suriye Krizi Karşısında İran'ın Tutumu ve Şam-Tahran İttifakının Temelleri," 154.

35 Meliha Altunışık, “Orta Doğu'da Bölgesel Düzen ve Arap Baharı," Orta Doğu Analiz 5, no. 53 (2013): 77.

36 Bajoghli \& Keshavarzian, "Iran and the Arab Spring," The Arab Spring: The Hope and Reality of the Uprisings, 175.

37 Bayram Sinkaya, “Arap Baharı Sürecinde İran'ın Suriye Politikası,” SETA Analiz, (Ankara: SETA, 2012), 10.

38 Seçil Özdemir, “İran'ın Bir Dış Politika Enstrümanı olarak Propaganda,” 20. 
dan korumak ve mezhepçilik söyleminden soyutlamak amacı ile propaganda yürütmektedir. İlk olarak, bölgede İran'ın politikaları ile uyuşmayan ya da İran'a eleştirel bakan aktörler İsrail ile hareket etmekle suçlanmaktadır. Buna ek olarak, bölge ülkelerinin ve bölge dışındaki güçlerin İran'a karşı sürekli bir mücadele içerisinde oldukları, İran'ın ilerlemesini istemedikleri ve İran'1 engellemek için her yolu denedikleri ileri sürülmektedir. İkinci olarak ise, eğer bu eleştirel aktörler İran içindeyse, devrim karşıtlığ 1 , devlet düşmanlığ 1 , işbirlikçilik ve vatana ihanet gibi söylemler ön plana çıkarılmaktadır. 2012 yapımı olan ve yönetmenliğini Abdülkasım Talebi'nin yaptığ 1 ve devlet tarafından da desteklenen Altın Tasmalar (Ghaladehaye Tala) ve 2016 yılında İbrahim Hatemikiya tarafindan yapılan Bodyguard filmleri bu bağlamda düşünülebilir. Altın Tasmalar, 2009 yılında İran'da yaşanan "Yeşil Devrim" sürecini ele almaktadır. 2009 yılında Hüseyin Musavi öncülüğünde başlayan "Yeşil Devrim", İran'da mevcut düzende reform yapılması talebi ile ortaya çıkmıştır. Filmde protestocular, Batı'ya ajanlık yapan ve İran' da mevcut rejimi yıkıp yerine Batı yanlısı bir rejim kurmayı amaçlayan kimseler olarak sunulmuştur. Bodyguard ise DMO'ya bağlı bir askerin nükleer enerji çalışmaları yürüten genç bir mühendisin korumal1ğını yapmasını ele almaktadır. Filmde sık sık İsrail ve Batılı güçler tarafından öldürüldükleri iddia edilen bilim insanları konu edilmektedir. Nükleer enerji konusu, İran'ın uluslararası ilişkilerinde öncelikleri arasındadır ve bağımsızlık ve itibar meselesi olarak görülmektedir. Tarihi dış güçlerin işgali, darbeler ve iç işlerine müdahale gibi olaylarla dolu olan İran'ın, hem devlet olarak, hem de toplumsal düzeyde 'komplocu' düşüncenin egemen olmasından dolayı, propaganda söylemlerinin karşılık bulduğu düşünülebilir. Bunların dışında İran, kötüye karşı her zaman iyinin yanında yer alan ve baskıcı güçlere karşı mazlum halkları savunan bir ülke olarak da işlenmektedir. "Şam Saatine Göre” filmi de bu kapsamda değerlendirilebilir. 


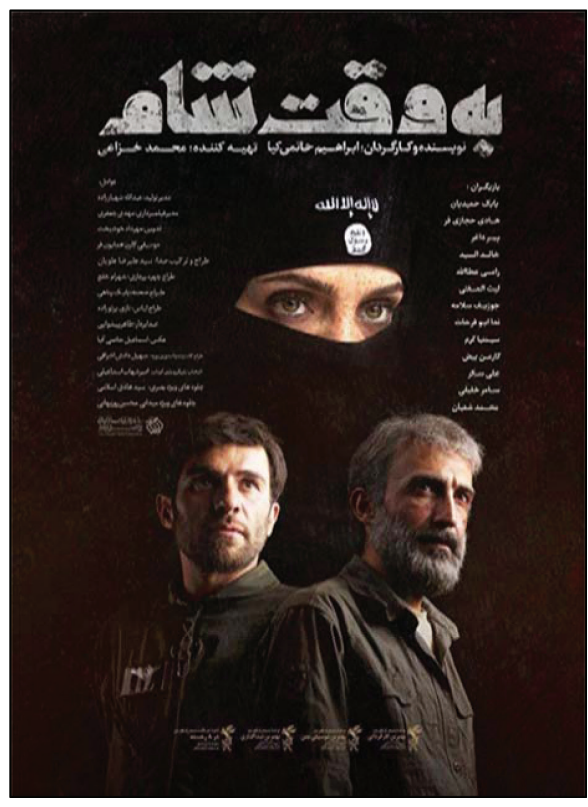

\section{Resim 1: Filmin tanıtımında kullanılan bir afiş}

\section{5. "Şam Saatine Göre" Filmi}

"Şam Saatine Göre", Farsça adı ile Be Vaghte Sham, yönetmenliğini ve senaristliğini İranlı yönetmen İbrahim Hatemikiya’nın yaptı̆̆ı ve 2018 y1linda gösterime giren bir propaganda filmidir. Film, Owj Sanat ve Medya Kurumu tarafından yapılmıştır. Bu kurumun, İran Hükümeti ve DMO ile bağlarının bulunduğu ve İran'ın yurtiçinde ve yurtdışında propaganda faaliyetlerini yürüttüğü iddia edilmektedir. ${ }^{39}$

Filmde, Ali karakterini Babek Hamidiyan, Yunus karakterini Hadi Hejazifer ve IŞİD komutanı Ebu Ömer Şişani’yi ise Joseph Saklameh canlandırmaktadır. Film, her ne kadar savaşın ve IŞİD katliamının korkunç sahnelerini gösteriyor olsa da, filmde işlenen hikâye bir savaş öyküsünden çok daha fazlasını ifade etmektedir. Film, ileride de değinileceği üzere İran'ın

39 Ishaan Tharoor, "Iran revs up for its latest Holocaust cartoon contest," Washington Post, 12 May1s 2016, https:/www.washingtonpost.com/news/worldviews/wp/2016/05/12/ iran-revs-up-for-its-latest-holocaust-cartoon-contest $/$ ?noredirect $=$ on\&utm_term $=$. ce9df258df2c 
propaganda aygitının bir tezahürü olarak değerlendirilebilse de, bugün son derece güncel olan birçok konuya da değinmektedir. Babalar ve oğullar arasındaki karmaşık bir ilişki, görev çağrısına karşı derinden hissedilen cevap verme ihtiyacı ve iyilik için kendini feda etme kavramları filmin hikâyesi içerisinde bütünleşmişlerdir. ${ }^{40}$

Film, İran' da önemli sayıda kişinin beğenisini toplamıştır ve İran' da son zamanların en çok izlenen filmlerden biri olmuştur. 41 "Fecr Film Festivali'nde üç dalda "Billur Simurg" kazanan filmin, Berlin Film Festivali'ne paralel olarak düzenlenen Avrupa Film Pazarı'nda da gösterileceği belirtilmiştir. ${ }^{42}$ Filmi seyredenler arasında İranlı yöneticiler de bulunmaktadır. İran'ın Suriye'deki savaşını yöneten ve 'İran'ın Orta Doğu'daki kılıcı' ${ }^{43}$ olarak adlandırılan DMO'nun Kudüs Gücü komutanı Kasım Süleymani, filmin yönetmeni ve senaristi İbrahim Hatemikiya'yı alnından öperek tebrik etmiştir. ${ }^{44}$ DMO'nun komutanlarından Muhammed Bagheri, filmin İran askerlerinin IŞīD’e karşı gösterdikleri kahramanlığını sergilediğini söylemiştir. ${ }^{45}$ İran Dışişleri Bakanı Cevad Zarif ise filmi, yönetmen Hatemikiya ile birlikte izlemiştir ve filmi sosyal medya hesabı aracılığıyla övmüştür. Zarif, sosyal medya hesabından paylaştığı yazıda, izlediği filmi eşsiz bir eser olarak yorumlamıştır. ${ }^{46}$

Bunların yanı sıra, filmin Tahran' da yapılan reklam ve tanıtımları da ilginç olaylara sahne olmuştur. Tahran'da bulunan alışveriş merkezlerinden Ku-

40 Robert Fantuna, "Damascus Time: An Iranian Movie," Counterpunch, 20 Nisan 2018, https://www.counterpunch.org/2018/04/20/damascus-time-an-iranian-movie/

41 Rick Sterling, "Damascus Time: An Iranian movie about ISIS in Syria," Investigaction, 25 May1s 2018, https:/www.investigaction.net/en/damascus-time-an-iranian-movieabout-isis-in-syria/

42 "Şam Saatine Göre" Avrupa Film Pazarı'nda gösterilecek," Mehr, 14 Şubat 2018, https://tr.mehrnews.com/news/1869303/\%C5\%9Eam-Saatine-G\%C3\%B6re-AvrupaFilm-Pazar\%C4\%B1-nda-g\%C3\%B6sterilecek

43 Serdar Ataş, “İran'ın Orta Doğu'daki Kılıcı: Kasım Süleymani,” Aljazeera, 11 Kasım 2014, http://www.aljazeera.com.tr/al-jazeera-ozel/iranin-ortadogudaki-kilici-kasimsuleymani

44 “Zarif; Şam Saatine Göre (2018) filmini övdü,” Yeni Kaynak, 19 Haziran 2019, http:// www.yenikaynak.com/haber/zarif-sam-saatine-gore-2018-filmini-ovdu.html

45 Mostafa Afzalzadeh, "Damascus Time:" A Drama Movie on the "Islamic State," Global Research, 14 Mart 2018, https://www.globalresearch.ca/damascus-time-adrama-movie-on-the-islamic-state-isis-daesh/5632018

46 "Kasım Süleymani, Şam Saatine Göre (2018) filminin yönetmenini tebrik etti," Yeni Kaynak, 19 Haziran 2019, http://www.yenikaynak.com/haber/kasim-suleymani-samsaaatine-gore-2018-filminin-yonetmenini-tebrik-etti.html 
ruş Alışveriş Merkezi'nde yapılan tanıtım kapsamında, silahlı ve cihatçı görünümlü bir grup erkek, "Allah-u Ekber!" diye bağırarak alışveriş merkezi içerisinde turlamaya başlamışlardır. IŞīD'in Çeçen kökenli komutanlarından Ömer Şişani'yi çağrışıtıran kızıl sakallı grup lideri de ata binmiş halde insanların arasında dolaşmıştır. Tekbir getiren silahlı adamların "Şam Saatine Göre" filminin tanıtımını yaptıkları ise daha sonra anlaşılmıştır. ${ }^{47}$ Film, 24 Ağustos 2018 tarihinden itibaren Suriye'de de gösterime girmiş ve Halep, Şam, Humus ve Lazkiye gibi kentlerde izlenmiştir. ${ }^{48}$ Suriye'yi, Lübnan ve Irak gösterimleri takip etmiştir.

\section{6. "Şam Saatine Göre” İran'ın Suriye Politikası}

"Şam Saatine Göre” filminin gösterime girdiği dönem, bölgede ve İran'da yaşanan çeşitli gelişmeler ile aynı zamana denk gelmektedir. Söz konusu dönemde IŞiD ile mücadele yoğunlaşmış ve örgüt büyük askeri kayıplara uğratılmıştır. İran ise bu dönemde mezhepçilik yaptı̆̆ 1 ve iç sorunlarından çok dış meseleler ile ilgilendiği gibi gerekçelerle hem uluslararası aktörlerden hem de iç kamuoyundan gelen eleştirilere maruz kalmıştır. Filmde İran'ın kendine yöneltilen eleştirilere karşı insan hakları, din ve vatanseverlik gibi olguları kullanarak söylem geliştirdiği görülmektedir.

\subsection{Mikro Yapılar}

Filmin görselleri, giriş ve sonuç bölümleri, Dijk'in mikro yapı çözümlemesi kapsamında ele alınmıştır.

\subsubsection{Filmin Görselleri}

Filmde kullanılan görsellerin birbirine zıt olacak şekilde resmedildiği görülmektedir. Soldaki afişte masumiyeti ve temizliği sembolize etmesi aç1sından beyaz ağıllıklı bir ton kullanılmıştır. Görselde, İranlı pilotlar (arkada) ve kucağında bebeği ile bir kadın resmedilmektedir. Sağdaki afişte ise siyah ağırlıklı bir renk seçimi vardır. Görselde, IŞiD'in canlı bombası olan

\footnotetext{
47 “Böyle Film Tanıtımı Olur Mu?," Sputnik, 9 Mayıs 2018, https://tr.sputniknews.com/ ortadogu/201805091033374635-film-tanitimi-tahran-avm-isid-baskini/

48 "Damascus Time set for Syria screening," Iran Daily, 2018, http://www.iran-daily. com/News/220125.html?catid=11\&title=-Damascus-Time--set-for-Syria-screening
} 
ve kaçırdığı uçak ile intihar saldırısı yapacak olan bir kadın resmedilmiştir. Kullanılan fona bakıldığında hem kara bir çarşaf giyinmiş IŞíD’li kadın bir militan, hem de bir uçak kokpiti görülmektedir. Görsellerde bir taraf hayatı sembolize ederken, diğer taraf ölüm ile eş değer tutulmaktadır.

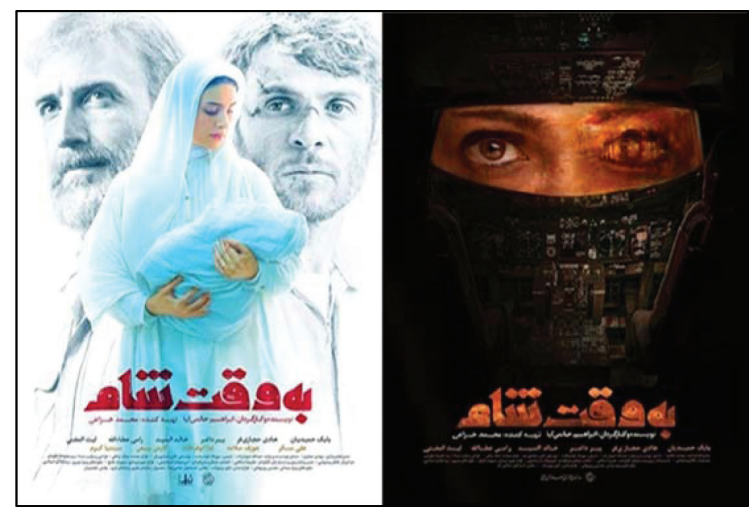

Resim 2: Filmin tanıtımında kullanılan afişler

\subsubsection{Filmin Girişi}

Filmin girişinde, Suriye'deki duruma ilişkin bir değerlendirme yapılmakta ve İran'ın savaştaki insani duruşu belirtilmektedir. Bu, filmde söylemi oluşturan ilk ögedir. Filmin konusuna dair bilgi veren giriş bölümü iletilmek istenen mesajla ilgili önemli ideolojik bilgiler vermektedir. Filmin girişinde Farsça olarak aşağıdaki metin yer almaktadır:

2010 yılının Ocak ayında çıkan iç savaş sebebiyle, Suriye bir krizin içerisine sürüklendi. IŞID lideri Ebubekir Bağdadi, Suriye ve Irak ta hükümet kurma sevdasindaydl. Şehirler birer birer düşerken, direnenler acımastz bir kuşatmaya maruz kaldılar. Büyük bir insanlık dramı yaşanıyordu ve havayolu dı̧̧ında erzak göndermenin imkânı yoktu. Iranlı pilotlar, insani yardım ulaştırılmasında öncü olanlardandl.

$\mathrm{Bu}$ girişle başlayan filmin ilk sahnesi, İranlı pilotların canları pahasına IŞSiD tehdidi altındaki Suriye'nin Fua ve Kefreyya bölgelerindeki sivillere havadan insani yardım götürmelerini anlatmaktadır. Aşağıdaki siviller, yukarıdan gelen İran'a minnet duymaktadırlar. Ancak aşağıdaki IşīD tehdidi, yardım paketlerini toplayan sivillere cinsiyet ve yaş gözetmeksizin saldırmaya devam etmektedir. Bu sahnede, IŞiD terörü ve İran'ın insani yardımı birbiriyle yakından ilişkili bir biçimde sunulmaktadır. 


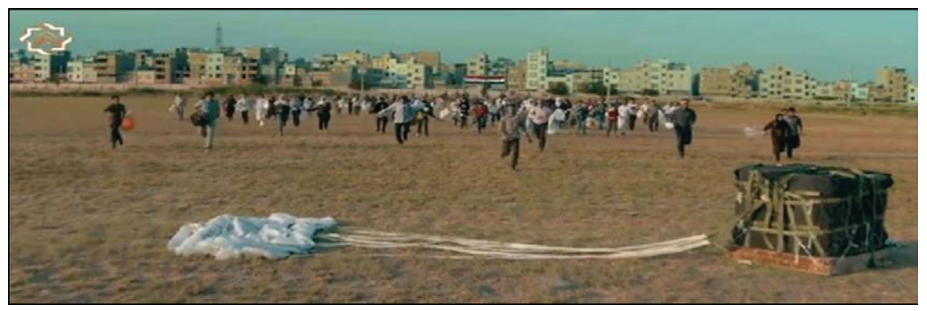

Resim 3: İran'ın hava yolu vasıtasıyla yaptığı yardımlar

\subsubsection{Filmin Sonu}

Film, IŞiD'in söz konusu uçak ile Şam'a yapmayı planladığı saldırı ile sona gelmektedir. Uçağ 1 , üzerine Şişani tarafindan hazırlanmış bomba yüklü yelek giydirilen İranlı pilot Ali ve IŞİD'li bir militan birlikte kullanacaklardır. Ali, uçak havadayken çıkan ve kendisinin de yaralandığı çatışmada IŞİD militanlarını öldürür ve ardından, babasının da dâhil olduğu tutsakları paraşütlerle uçaktan atarak kurtarır. Geride sadece uçağı kullanan militan kalmıştır. Ardından, uçak Şam'da intihar saldırısı yapamadan, Ali'nin üzerindeki bomba yüklü gömleği patlatmasıyla havada infilak eder. Film, intihar saldırısının hedefindeki şehirde İranlı pilotun yaşamı pahasına kurtardığı çocukların sesleri ve görüntüleri ile sona ermektedir. Filmin sonunda, filmin "başsız kahramanlar silsilesinin serdarı Hüseyin bin Ali'ye ve günümüzde bedenleri Şam topraklarında yatan tüm şehitlere" armağan edildiği yazmaktadır. Son sahne ile İran'ın ve İranlıların insani yönlerine vurgu yapılmakta ve kendisinin de bir çocuğu olan babanın başka masum çocuklar için hayatını feda ettiği görülmektedir.

\subsection{Makro Yapılar}

Filmin olay örgüsü, mekânı, karakterleri ve bunların temsili, Dijk'in makro yapı çözümlemesi kapsamında ele alınmıştır.

\subsubsection{Olay Örgüsü}

Filmde, İran'ın Suriye'de IŞi̇D'e karşı mücadelesi, ikisi de pilot olan bir babanın (Yunus) ve oğlunun (Ali) IŞì tarafından kuşatılmış olan Palmira kentindeki sivilleri oradaki havaalanında bulunan bir uçak ile kurtarma 
mücadeleleri etrafında işlenmektedir. Her ne kadar İranlı pilotlar sivilleri kurtarmış ve Palmira'dan havalanmış olsalar da, uçakta bulunan Işì'li mahkûmlar uçağın kontrolünü ele geçirecekler ve uçağı Palmira'ya geri götürmek isteyeceklerdir. Bu minvalde gelişen hikâye, IŞ่̇D’li militanların aynı uçakla Şam'a yapmayı planladıkları bir intihar saldırısının İranlı pilot Ali tarafindan hayatı pahasına durdurulması ile son bulmaktadır.

\subsubsection{Mekânlar ve Temsil}

Filmin anlatısı içinde Suriye'nin iç savaş öncesi ve sonrası temsilleri arasındaki fark hissettirilmektedir ve iç savaşın yarattığı yıkımın altı çizilmektedir. Filmde, Suriye harap, yıkık ve dökük bir ülke olarak gösterilmektedir. Öyle ki, artık havaalanları kullanılamadığı için hayvan otlatılacak yerlere dönüşmüşlerdir. Filmin uzun bir bölümü ise uçak içinde geçmektedir. Uçaktakilerin kötü durumda ve yardıma muhtaç oldukları görülmektedir.

\subsubsection{Karakterler ve IŞíD’in Temsili}

Filmin ana karakterleri pilot Ali ve babasi pilot Yunus olmakla beraber, yan karakterler olarak IŞiD şeyhi ve militanları da sayılabilir. Ali, filmde mazlumlara hizmet etmeyi önemli bir görev sayan bir karakter olarak sunulmaktadır. Öyle ki, insani yönü ve göreve olan bağlılı̆̆ kendi hayatının da önüne geçmiştir. Ali'nin babası Yunus ise benzer bir karakter olarak sunulmaktadır. Ancak oğlu ile geçmişten gelen bir soğuk ilişkiye sahiptir. Uzun görevler nedeniyle oğlundan uzak kalmıştır ve bu, ilişkilerine de yansımıştır. Şam Havaalanı'nda geçen sahnede, sivil halka yardım götüren İranlı pilotlardan birisi olan Ali'nin görev süresi bu son görev ile dolmaktadır ve artık İran'a dönme zamanı gelmiştir. İran'da kendisini bekleyen hamile bir eşi (Leyla) vardır. Ali, eşini uzun zamandır görmemiştir. Ali’ye İran'a geri dönmesi için belgelerini yine bir pilot olan babas1 Yunus getirmiştir. Ali'nin İran'a dönmesinin ardından, Yunus, Palmira'da IŞiD tehdidinden kaçarak havaalanına sığınmış olan sivilleri Şam'a getirecek bir planı uygulamaya başlayacaktır. Plana göre, İranlı pilot Palmira şehrine sızacak ve orada bekleyen sivilleri havaalanındaki uçakla tahliye ederek kurtaracaktır. Bu tahliye planı görevi, Yunus'a verilmesine rağmen, oğlu Ali de sivillerin kurtarılmasında son bir hizmet yapmak istemektedir ve İran'a dönmekten vazgeçmiştir. Palmira'ya gidecek olan helikoptere giz- 
lice binen Ali, burada karısından gelen videoları izlerken görülmektedir. Videodan anlaşılacağı üzere, hamile olan karısı rahatsızlanmıştır ve annesi tarafından hastaneye kaldırılmıştır. Videonun devamında Leyla'nın annesi görülmektedir ve Ali'ye şunları söylemektedir:

Bize verdiğin söz bu muydu Ali? Kızımı bırakıp başka topraklara gitmen doğru değil. Insan hem Hüda'yl, hem de hurmayı isteyemez. ${ }^{49} \mathrm{O}$ uçaklarda pilot olman daha önce de Leyla'yl tedirgin etti ve sonunda da çocuğunu kaybetti. Yine çocuk istiyoruz dediniz, tamam dedik. En azından ailenin yanında ol! Allah şahit ki, kendi memleketimizde de az sorunumuz yok! Bir şeyler yapmak istiyorsan kendi memleketinde yap! Allah korusun, bu çocuk da diğeri gibi olursa Leyla'yı unut!

Ancak Ali bu sözleri duymasına rağmen İran'a geri dönmemektedir. İran'ın sivilleri ve mazlumları önceleyen tavrı öne çıkmakta ve Ali, karısı ile çocuğunu kaybetme riskini göze alarak daha erdemli olduğunu düşündüğü bu göreve gitme kararından vazgeçmemektedir. Leyla'nın annesinin "kendi memleketimizde de az sorunumuz yok. Bir şeyler yapmak istiyorsan kendi memleketinde yap" sözü, İran'ın bölgedeki direniş örgütlerine yaptığı maddi ve lojistik yardımların ve Suriye'deki savaşa girmesinin yol açtı̆̆ 1 maddi ve beşeri külfetin eleştirisini yapan İranlı muhaliflere yönelik bir mesaj olarak düşünülebilir. ${ }^{50}$ İran'ın bölgedeki silahlı örgütlere yardımı ve Suriye'deki iç savaşa dâhil olması, İran içinden çok sayıda eleştirinin yükselmesine neden olmuştur. Özellikle 2009 yılındaki gösterilerden sonra, halk İran'ın ülke dışındaki faaliyetlerine tepki göstermeye başlamıştır. Ülke içerisinde artan ekonomik sorunlara rağmen İran'ın bölgedeki örgütlere sağladığı yardımlar ve İran dışındaki operasyonlarda çok sayıda askerin hayatını kaybetmesi rejimin eleştirildiği konulardır. Halkın tepkisi, "Ne Gazze, Ne Lübnan, Canım Feda İran" ve "Suriye'yi bırak, bize bak" gibi sloganlardan da anlaşılmaktadır. ${ }^{51}$ Najad'a göre 1980 ve 1988 yılları arasındaki İran-Irak Savaşı'nda toplumsal gösteri haline gelen ve kamu-

49 İstediği şey fedakârlık gerektirdiği halde fedakârlığa yanaşmamayı, ama istediğinden de vazgeçmemeyi ifade eden bir İran atasözü. Türkçedeki 'ne yardan ne de serden geçmek' ifadesi ile benzer bir anlama sahiptir.

50 Payman Asadzade, "Iran's involvement in Syria is costly. Here's why most Iranians still support it," Washington Post, 17 Ekim 2017, https://www.washingtonpost.com/ news/monkey-cage/wp/2017/10/19/irans-involvement-in-syria-is-costly-heres-whymost-iranians-still-support-it/?noredirect $=$ on\&utm_term $=.4920 \mathrm{fa} 07 \mathrm{aabb}$

51 Ali Fathollah Najad, 'Iranians respond to the regime: 'Leave Syria alone!,' Aljazeera, 2 Mayıs 2018, https://www.aljazeera.com/indepth/opinion/iranians-respond-regimeleave-syria-180501081025309.html 
ya açık yapılan asker cenazesi törenleri, Suriye'deki iç savaş sonrasında yapılmamaya başlanmıştır. ${ }^{52}$ Rejim, Suriye'de hayatını kaybeden askerleri kamusal alanın dışında defnetmekte ve ölümler gizlenmeye çalışılmaktadır. Film, bu eleştirilere de yer vermekte ve rejimin faaliyetlerine meşruiyet kazandırmaya çalışmaktadır. Sonuç itibariyle İran'a göre, Tahran'ın savunması Şam'dan, Lübnan'dan başlamaktadır ve Suriye'de savaşmak veya Hizbullah'a destek vermek, İran'ın güvenliğinin de bir parçasıdır.

Ali'nin bu tavrı, İranlı komutanların arasındaki konuşmada da göze çarpmaktadır. İran, yardım gerektiren durumda müttefiki Suriye'yi yalnız bırakmamakta ve sorumluluk almaktadır:

- Asker: Peki Suriyeli pilotlar nerede efendim?

- Komutan: Hepsi şu an uçuşta. Onlar gelinceye kadar geç olabilir dediler. Şimdilik biz daha hazır durumdayız.

- Asker: Ruslardan neden yardım istememişler?

- Komutan: Şimdilik vazife bizim.

Palmira'ya sızan Ali ve Yunus, havaalanına giderek sivillerle bir araya gelirler. Tahliye işlemi gece başlayacaktır ve her an IŞiD saldırısına uğrama ihtimalleri bulunmaktadır. Ali'nin pilot koltuğunda oturduğu uçak, içerisindeki siviller ve rehin alınmış IŞìD'li militanlarla birlikte havalanır. Siviller, kendilerine yapılan işkenceleri ve katliamları hatırlatarak uçakta bulunan Suriye askerlerinden IŞİD'lilerin esir alınmamasını ve hemen öldürülerek cezalandırılmalarını isterler. Bu noktada film, IŞiD'in İslam anlayışına eleştiri getirmektedir:

- Sivil: Bunlar çocuklarımızı öldürdüler. Hangi vicdan bunların yaşamasina izin verir?

- Asker: İşimiz intikam almak değil. Unutmayın, biz insanız. Bunlar gibi canavar değiliz. İslam'ı bunlar değil, bizler yaşıyoruz.

Havalanan uçak bir müddet sonra, sivillerin arasına karışmış IŞiD sempatizanı bir kadının çıkardığı bir kargaşa içerisinde IŞİiD'li bir rehineye bıçak vermesi ve daha sonra bu rehinenin kendisini ve arkadaşlarını kelepçelerden kurtararak Suriye askerlerini öldürmeleri ile IŞíD'in kontrolü altına girecektir. Uçağa hâkim olan IŞíD’liler, İranlı pilotlardan tekrar Palmira’ya

52 Ali Fathollah Najad, "Iran: Fighting 'terror' publicly, mourning the dead secretly," Aljazeera, 1 May1s 2018, https://www.aljazeera.com/indepth/opinion/iran-fightingterror-publicly-mourning-dead-secretly-180430140249437.html 
dönmelerini isterler ve dönmemeleri durumunda uçaktaki sivilleri öldüreceklerini ilan ederler. Bu noktada, İranlılar ve IŞṠ̇'liler arasında geçen konuşmalarda İranlılara 'mürtet' ve 'kâfir' gibi kelimelerle hitap edildiği görülmektedir. İranlılar böylelikle IŞi̇D’in kendi inançlarından başka inanç tanımaz fikirlerinden mustarip ve masum olarak resmedilmektedirler. İranlılar, IŞi̇D tehdidine karşı uyarılmaktadır ve IŞi̇D’e karşı mücadele eden devletin arkasında birleşmeleri amaçlanmaktadır. Burada İranlılara, IŞSiD'in kendileri hakkındaki düşüncelerinin net olduğu, IŞiD'in Şiileri din dışı ve katli vacip gördüğ̈̈ mesajı verilmektedir. İranlıların yapması gereken, bu tehdide karşı bir arada olmak ve devlete destek vermektir.

İranlı pilot Yunus ve IŞi̇D’liler, kadınların ve çocukların uçaktan indirilmeleri ve kalanlarla beraber Palmira'ya dönmeleri konusunda pazarlık ederler ve anlaşırlar. IŞi̇D'lilere Palmira' 1 bir şeyh liderlik etmektedir. Burada tekrardan İranlı pilotun sivil yaşamına ve insani değerlere verdiğ önemin altı çizilmektedir. IŞİD için sivillerin hayatı pazarlık unsuru olarak araçsallaştırılırken, İranlı pilotun insani ve ahlaki tavrı öne çıkmaktadır.

Uçağın Palmira'ya doğru yeniden yola çıkması ile birlikte İranlılar ve IŞi̇D şeyhi arasındaki konuşmalar da artmaktadır. Savaşan iki tarafi temsil eden bu diyalogda, İran'ın gözündeki IŞi̇D imgesi ve IŞİD'in ötekileştirici tavrı ortaya çıkmaktadır:

- Şeyh: İnşallah yeryüzünün haritası değişir ve herkes bir gün hilafet bayrağınin altına girer. Bugün Irak ile Suriye ve yarın Iran.

Iranlı pilot buna güler. Şeyh sözlerine devam eder:

- Komik mi? Bir gün senin için Tahran'a geleceğim. Tabi eğer hayatta olursan ve hilafet orduları tarafindan öldürülmezsen.

- Iranlı: İran'a ulaşmak için yolunuz uzun, ama İsrail hemen yanı başınızda. Orayı neden fethetmiyorsunuz?

- Şeyh: Bizim derdimiz Yahudiler değil. İslam iddiasında bulunan ülkeler. Rafizi Iran, Allah'ın evini işgal etmiş Suudiler ya da münafik Osmanlı Türkleri gibi.

- Iranll: Sen bu sözlere inaniyor musun?

- Şeyh: Ben bir ömür cihad için bekledim. Canım, Ebubekir Bağdadi'ye feda olsun. 


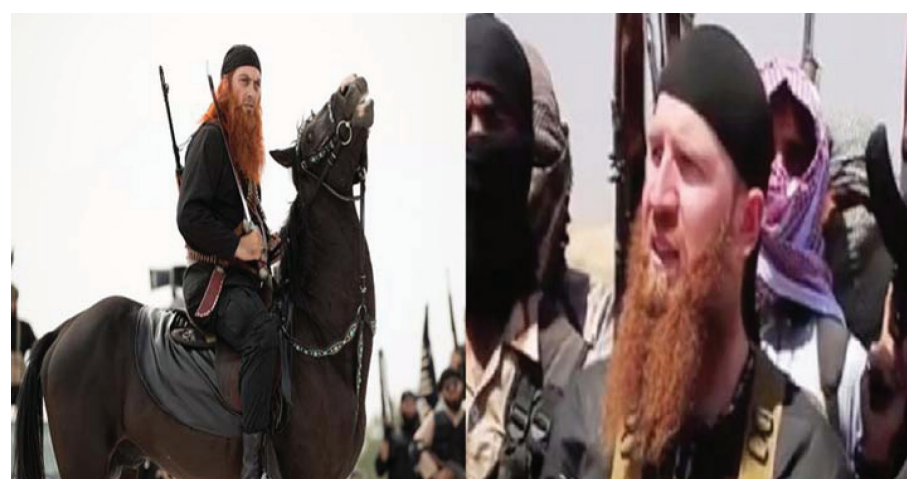

Resim 4: Filmde (sol) ve gerçek hayatta (sağ) Ömer Şişani.

$\mathrm{Bu}$ diyalog ile amaçlanan, IŞİD tehlikesine karşı hem İran kamuoyunu hem de dünyayı uyarmaktır. İran'a göre İslam adına savaşmak İsrail'i hedef almayı da kapsamaktadır. Ancak IŞİD’in İsrail yerine Türkiye, Suudi Arabistan ve İran gibi Müslümanların çoğunluk olarak yaşadıkları yerleri tehdit etmesi ile onun İslam adına savaşmadığı izlenimi uyandırılmaktadır. ${ }^{53}$ Diğer taraftan, sahada farklı örgütleri destekleyen ve farklı siyasal çıkarları olan İran, Suudi Arabistan ve Türkiye'nin aslında aynı tehdide karşı savaştıkları gösterilmektedir. ${ }^{54}$

Uçağı Palmira'da Ömer Şişani liderliğindeki IŞİD ordusu beklemektedir. Bu noktada, Şişani karakterini canlandıran oyuncunun gerçek Şişani'ye benzer bir biçimde kızıl bir sakala sahip olduğu unutulmamalıdır. Şişani, şeyhi İranlılar ile pazarlık etmek ve anlaşma yapmakla suçlar ve kâfirle anlaşma yapmanın cezası olarak şeyhin kafasını kılıcıyla keser. Böylelikle, IŞİD'in acımasızlığı ve vahşeti kendi militanlarını da öldürmeleri üzerinden seyirciye hatırlatılır. Seyirci, IŞİD'in şiddetini ve fanatizmini görür.

53 IŞiD'in Suudi Arabistan'1 hedef göstermesi kısmı tartışmaya açık bir konudur. 1979'daki devrimden bugüne kadar Kâbe'nin ABD ve İsrail ile işbirliği yapan Suudi rejimi tarafından işgal edildiği iddiası İran tarafından savunulmaktadır. Hatta kimi uluslararası toplantılarda Kâbe'ye uluslararası statü kazandırılması da İran öncülüğünde tartışılmaktadır. Filmdeki diyalogda Kâbe'nin Suudiler tarafından işgal edildiği iddiası tarafımca aslında İran'a ait olan bir fikrin IŞ่̇D'in ağzından dile getirildiği şeklinde değerlendirilmektedir.

54 Filmin önemli mesajlarından birisi de Hristiyan bir kadının IŞṠD'li bir militan tarafından köle yapılmak istenmesine İranlılar'ın karşı çıkarak kadını kurtarmalarıdır. Böylelikle, Müslüman olmayan kamuoyuna IŞİD'in amaçları ve uygulamaları hatırlatılmakta ve İran bayrağı altında birleşme çağrısı yapılmaktadır. 
Militanlar insani duygularla hareket etmemekte olup mezhepçi ve nefret dolu bir dile sahiplerdir. Takip eden sahnelerde, IŞiD'in işkence ve katl videolarının ve işkencelerinin örneklerine rastlanmaktadır. Son olarak, filmde İranlılar aklıselime sahip, düşünerek hareket eden ve insani amaçlar ile yaşayan insanlar olarak gösterilmiştir. IŞi̇D militanları ise tam aksine akıllıca olmayan ve düşünmeden hareket eden insanlar olarak aktarıldığını belirtmekte fayda vardır. Filmde, IŞiD'li militanlar aklen dengesiz ve gerçek hayat ile mesafeli olarak karakterize edilmektedir. Örneğin bir militan bir yandan uçağ 1 gitmek istedikleri yere yönlendirmek isterken, diğer taraftan uçağın uçuş sistemine zarar verecek şekilde kokpitte ateş açmaktadır.

\section{Sonuç}

Teun A. Van Dijk'in geliştirdiği eleştirel söylem analizi yöntemi, son zamanlarda ideoloji, söylem ve dil gibi kavramlar üzerinde durarak ideolojik çıktıların bu kavramlar ile ilişkisini çözümlerken sıklıkla kullanılmaktadır. $\mathrm{Bu}$ yöntem, metinleri ve bağlamlarını bir arada değerlendirmekte ve taşıdıkları anlamları çözümlemektedir. Çalışmada bu kapsamda, İran'ın propaganda faaliyetlerini göstermesi açısından 2018 yılında gösterime giren "Şam Saatine Göre" filmi eleştirel söylem analizi yöntemi bağlamında ele alınmıştır. Film, IŞiDiD ile çatışmaların yaygınlaştığı ve İran'a yönelik içerden ve dişardan eleştirilen arttığı bir dönemde izleyiciye sunulmuştur. $\mathrm{Bu}$ dönem, iç savaşa dahline yönelik eleştirilerden bunalan İran'ın kendisine meşru bir zemin sağlamaya çalıştı̆̆ bir dönemdir.

Filmin ideolojik söyleminin merkezinde İran'ın Suriye'deki iç savaşı alg1layışı ve kendisine biçtiği rolün gösterilmesinin yanı sıra, ulusal ve uluslararası aktörlere İran'ın pozisyonunun sergilenmesi yer almaktadır. Buradan hareketle, İran'ın savaş süresince göstermiş olduğu insani ve barışç11 politikaların altı çizilmiştir. İran'ın insanı ve barışı önceleyen yaklaşımı, filmin girişinde gösterilen hava yardımları, İranlı pilotların hal ve tavırları ve filmin tanıtımında kullanılan görseller ile gösterilmiştir. Film afişlerinde kullanılan görsellerde beyaz ve siyah gibi birbirinden keskin bir biçimde farklı renk tonlarının kullanıldığı görülmektedir. Bunun İran'ı olumlarken beyaz tonların, IŞiD'e biçilen acımasız ve zalim rolü gösterilirken ise siyah tonların kullanımından tezahür ettiği görülmektedir. Filmde IŞSiD karakterleri acımasız ve akıl sağlığ 1 sorunlu kişiler olarak temsil edilirken, 
İranlı karakterlerin aklıselim, insani ve kahramanca yönleri ön plana çıkarılmaktadır. Filmin taşıdığı söylem, IŞi̇D'in tüm insanlar için tehlikeli olduğudur. İran da pozisyonunu bu tespitten hareketle oluşturmaktadır. Buna göre İran'ın mevcut politikaları ve Suriye stratejisinin doğruluğu vurgusu yapılmaktadır. Bu bağlamda eleştirel pozisyondaki ulusal ve uluslararası aktörlere mesaj iletilmek istenmektedir.

Sonuç olarak, 1979 yılındaki devriminden bu yana propaganda filmlerini etkin bir şekilde kullanan İran'ın "Şam Saatine Göre” filmi ile bu alanda ilerleme kaydettiği düşünülebilir. Irak ile sekiz yıl süren savaşı konu eden ya da Amerikan karşıtlı̆̆ 1 temalı filmleri ile karşılaştırıldığında "Şam Saatine Göre" filminin etkisinin yerel ile sınırlı kalmadığı ve uluslararası alanda da etkili olmayı amaçladığg söylenebilir.

\section{Kaynakça}

Altunışık, Meliha. "Orta Doğu'da Bölgesel Düzen ve Arap Baharı," Orta Doğu Analiz 5, no. 53 (2013): 77.

Ayhan, Bünyamin, ve Çifçi, Muhammet Emin. "IŞİD, Propaganda ve İslamofobi," Medya ve Din Araştırmaları Dergisi 1, no. 1 (2018): 1732 .

Bajoghli, N ve Keshavarzian, A. "Iran and the Arab Spring," (Ed.) Haas, M ve Lesch, D, The Arab Spring: The Hope and Reality of the Uprisings, (Westview Press: Boulder, 2017), 174-193.

Batur, Sabire. Siyasal İslam Sinemast Örneğinde Iran Sinemast, (Yayımlanmamış Doktora Tezi: Dokuz Eylül Üniversitesi Güzel Sanatlar Enstitüsü, İzmir, 2007).

Chelkowski, Peter, ve Dabashi, Hamid. Bir Devrimi Sahnelemek: Iran Islam Cumhuriyeti'nde Propaganda Sanat,, (The Kitap Yayınlar1: İstanbul, 2018).

Conduit, Dara. "Hizballah in Syria: The Limits of the Democracy/ Moderation Paradigm," Orta Doğu Etütleri 5, no. 2 (2014): 81-114.

Çakı, Caner. "İran-Irak Savaşında Kullanılan İran Propaganda Posterlerinin Göstergebilimsel Analizi," İan Çalışmaları Dergisi 2, no. 1 (2018): 11-39. 
Devictor, Agnes. "Classic Tools, Original Tools: Cinema and the Public Policy in the Islamic Republic of Iran (1979-1997)," (Ed.). Tapper, R. The New Iranian Cinema: Politics, Representation and Identities, (I.B. Tauris: Londra \& New York, 2012), 66-76.

Ehteshami, Anoushirvan. Iran: Stuck in Transition, (Routledge: Londra, 2017).

Ekinci, Barış Tolga. "Argo Filmi Bağlamında Hollywood Sinemasında Söylem ve Yeni Oryantalizm," Atatürk İletişim Dergisi, (6), (2014).

Elhan, Nail. "Banal Nationalism in Iran: Daily Re-Production of National and Religious Identity," Insan ve Toplum 6, no. 1 (2016): 119-136.

Elhan, Nail. "İran'ın Uluslaşma Sürecinde Süreklilik ve Değişim: Banknotlar ve Posta Pulları Üzerine Bir İnceleme," Akademik Orta Doğu 11, no. 2 (2017): 85-97.

Hazır, Agah. "Suriye İç Savaşı'nda Müzik Cephesi: Örgütler ve Şarkılar Üzerine Bazı Gözlemler,” Orta Doğu Analiz 7, no. 71 (2015): 80-82.

Hazır, Agah. "Reflections on Musical Propaganda in the Syrian Civil War: A Comparison of the PKK/PYD, Daesh and Hezbollah," (Ed.). Küçüksolak, Ö. \& Yıldı, A. M. Current Debates in International Relations \& Law, (IJOPEC Publication: Londra, 2018), 169-177.

İnceoğlu, Çağrı. "Sovyet Propaganda Animasyonlarında Bat1 ve Batılı İmgesi," Galatasaray Üniversitesi İletişim Dergisi 19, (2013): 23-40.

Jowett, Gart, ve O'Donnell, Victoria. Propaganda and Persuasion, Londra: SAGE Publications, 2006.

Özdemir, Seçil. “İran'ın Bir Dış Politika Enstrümanı olarak Propaganda,” IRAM Analiz, Ankara: İran Araştırmaları Merkezi, 2017.

Risseeuw, Rafke. "The Syrian-Iranian Nexus: a Historical Overview of Strategic Cooperation," Research, Brussels: Brussels International Center for Research and Human Rights, 2018.

Robb, David. L. Operation Hollywood: How the Pentagon Shapes and Censors the Movies. New York: Prometheus Books, 2014.

Shafique, M. U. \& Khan, T. A. "Hollywood Propaganda Movies and Muslims," Journal of Mass Communication 8, (2013): 65-77. 
Sharma, Rajanda Kumar. Social Change and Social Control, Yeni Delhi: Atlantic Publishers, 1997.

Shaw, Tony. Hollywood's Cold War, Edinburgh: Edinburgh University Press, 2007.

Shaw, Tony. Cinematic Cold War: The American and Soviet Struggle for Hearts and Minds, Kansas: University Press of Kansas, 2010.

Shirinpour, Mahrokh . Iran Sinemast, İstanbul: Es Yayınları, 2017.

Sinkaya, Bayram. "İran-Suriye İlişkileri ve Suriye'de Halk İsyanı," Orta Doğu Analiz 3, no. 33 (2011): 38-48.

Sinkaya, Bayram. "Arap Baharı Sürecinde İran'ın Suriye Politikası," SETA Analiz, Ankara: SETA, 2012.

Sinkaya, Bayram. "Suriye Krizi Karşısında İran'ın Tutumu ve Şam-Tahran İttifakının Temelleri," Akademik Orta Doğu 10, no. 1 (2015): 131-160.

Sinkaya, Bayram. “İan'ın Suriye Stratejisi,” Akademik Orta Doğu, 11 (2), (2017): 49-64.

Stojanova, C. "The Great War: Cinema, Propaganda, and The Emancipation of Film Language," Acta Universitatis Sapientiae, Film and Media Studies 14, (2017): 131-156.

Şen, Gülriz. "İran ve Arap Baharı: Bağlam, Söylem ve Siyaset," Orta Doğu Etütleri 3, no. 2 (2012): 95-118.

Uskowi, Nader. Temperature Rising: Iran's Revolutionary Guards and Wars in the Middle East, Rowman \& Littlefield: Londra, 2019.

Uygur, Hakk1. "İran ve Arap Baharı," SETA Analiz 52, Ankara: SETA, 2012.

Van Dijk, Teun A. "Principles of Critical Discourse Analysis," Discourse \& Society 4, no. 2 (1993): 249-283.

Zor, Lokman. "Van Dijk'in Eleştirel Söylem Analizinin Sinema Filmlerine Uygulanması ve Kazakistan Sineması'ndan Örnek Bir Film Çözümlemesi: Stalin'e Hediye,” Akademik Bakış Dergisi 61, (2007). 


\section{İnternet Kaynakları}

Afzalzadeh, Mostafa . "Damascus Time": A Drama Movie on the "Islamic State," Global Research, 28 Şubat 2019, https://www.globalresearch.ca/damascus-time-a-drama-movie-on-theislamic-state-isis-daesh/5632018.

Ansari, Ali. “İran Yazı, Arap Baharı'na Karş1,” Aljazeera, 25 Ocak 2019, http://www.aljazeera.com.tr/gorus/iran-yazi-arap-baharina-karsi.

Asadzade, Payman. "Iran's involvement in Syria is costly. Here's why most Iranians still support it," Washington Post, 12 Kasim 2018, https://www.washingtonpost.com/news/monkey-cage/wp/2017/10/19/ irans-involvement-in-syria-is-costly-heres-why-most-iranians-stillsupport-it/?noredirect $=$ on\&utm_term $=.4920 \mathrm{fa} 07 \mathrm{aabb}$.

Ataş, Serdar. İran'ın Orta Doğu'daki Kılıcı: Kasım Süleymani,” Aljazeera, 11 Kasim 2017,

http://www.aljazeera.com.tr/al-jazeera-ozel/iranin-ortadogudakikilici-kasim-suleymani.

BBC, "IŞiD'in Yeni Propaganda Aracı: İnstagram.” Son erişim: 11 Kasım 2018 ,

https://www.bbc.com/turkce/haberler-dunya-41360381.

Bunker, Robert. Strategic Insights: The Assad Regime and Chemical Weapons, Strategic Studies Institution, 11 Kasim 2018, https://ssi.armywarcollege.edu/index.cfm/articles/Assad-RegimeChemical-Weapons/2018/05/18.

Fantuna, Robert. "Damascus Time: An Iranian Movie," Counter Punch, 11 Kasim 2018, https://www.counterpunch.org/2018/04/20/damascus-time-an-iranianmovie/.

İran Daily, "Damascus Time set for Syria screening." Son erişim: 28 Şubat 2018,

http://www.iran-daily.com/News/220125.

html?catid=11\&title=-Damascus-Time--set-for-Syria-screening.

Mehr. "Şam Saatine Göre Avrupa Film Pazarı'nda gösterilecek," Son erişim: 10 Kasim 2018, https://tr.mehrnews.com/news/1869303/\%C5\%9Eam-Saatine-G\%C3\%B6 re-Avrupa-Film-Pazar\%CC4\%B1-nda-g\%C3\%B6sterilecek. 
Najad, Ali Fathollah. "Iran: Fighting 'terror' publicly, mourning the dead secretly," Aljazeera, 28 Şubat 2018, https://www.aljazeera.com/indepth/opinion/iran-fighting-terrorpublicly-mourning-dead-secretly-180430140249437.html.

Najad, Ali Fathollah. "Iranians respond to the regime: 'Leave Syria alone!," Aljazeera, 28 Şubat 2018, https://www.aljazeera.com/indepth/opinion/iranians-respond-regimeleave-syria-180501081025309.html.

Sputnik. "Böyle Film Tanıtımı Olur Mu?," Son erişim: 10 Kasım 2018, https://tr.sputniknews.com/ortadogu/201805091033374635-filmtanitimi-tahran-avm-isid-baskini/.

Sterling, Rick. "Damascus Time: an Iranian movie about ISIS in Syria," Investigaction, 11 Kasim 2018, https://www.investigaction.net/en/damascus-time-an-iranian-movieabout-isis-in-syria/.

Tharoor, Ishaan. "Iran revs up for its latest Holocaust cartoon contest," Washington Post, 3 Mart 2019, https://www.washingtonpost.com/news/worldviews/wp/2016/05/12/ iran-revs-up-for-its-latest-holocaust-cartoon-contest/?noredirect $=$ on $\&$ utm_term=.ce9df258df2c.

Yeni Kaynak. "Kasım Süleymani, Şam Saatine Göre (2018) filminin yönetmenini tebrik etti," Son erişim: 10 Kasım 2018, http://www.yenikaynak.com/haber/kasim-suleymani-sam-saaatinegore-2018-filminin-yonetmenini-tebrik-etti.html.

Yeni Kaynak. "Zarif; Şam Saatine Göre (2018) filmini övdü," Son erişim: 10 Kasim 2018, http://www.yenikaynak.com/haber/zarif-sam-saatine-gore-2018filmini-ovdu.html. 